УДК 311

DOI https://doi.org/10.32689/2523-4625-2020-1(59)-10

\title{
Оксана ЦМОШИНСЬКА
}

кандидат економічних наук, доцент, заступник завідувача кафедри обліку і оподаткування, ПрАТ «ВНЗ «Міжрегіональна Академія управління персоналом», вул. Фрометівська, 2, м. Київ, Україна, 03039

ORCID: 0000-0002-2277-3317

\section{Галина КРИШТАЛЬ}

доктор економічних наук, доцент кафедри обліку і оподаткування, ПрАТ «ВНЗ «Міжрегіональна Академія управління персоналом», вул. Фрометівська, 2, м. Київ, Україна, 03039

ORCID: 0000-0003-3420-6253

\section{Oksana TSIMOSHYNSKA}

Doctor of Economic Sciences, Associate Professor at the Department of Accounting and Taxation, Interregional Academy of Personnel Management, 2 Frometivska str., Kyiv, Ukraine, 03039 ORCID: 0000-0003-3420-6253

\section{Halyna KRYSHTAL}

Candidate of Economic Sciences, Associate Professor, Deputy Head of the Department of Accounting and Taxation, Interregional Academy of Personnel Management, 2 Frometivska str., Kyiv, Ukraine, 03039 ORCID: 0000-0002-2277-3317

\section{АДМІНІСТРУВАННЯ ОРГАНІЗАЦІЙ ПУБЛІЧНОГО СЕКТОРУ ТА НОВІ МОЖЛИВОСТІ ВНУТРІШНЬОГО АУДИТУ \\ ADMINISTRATION OF PUBLIC SECTOR ORGANIZATIONS AND NEW POSSIBILITIES OF INTERNAL AUDIT}

Проблема розвитку внутрішнього аудиту в Украӥні фінансових компаній полягає у виробленні комплексного підходу, який би забезпечив умови для створення та ефективного функиіонування служб внутрішнього аудиту на фінансових підприємствах. У сучасних умовах управління впровадження служби внутрішнього аудиту дозволяє мінімізувати ризик банкрутства фінансових компаній, що являється позитивним сигналом для потенційних контрагентів та підвищує інвестиційну привабливість фінансових компаній.

Ключові слова: внутрішній аудит, служба внутрішнього аудиту, фінансові компанії, інвестииії.

The problem of development of internal audit in Ukraine of financial companies is to develop a comprehensive approach that would provide conditions for the creation and effective functioning of internal audit services in financial enterprises. In modern conditions, the management of the internal audit service minimizes the risk of bankruptcy of financial companies, which is a positive signal for potential counterparties and increases the investment attractiveness of financial companies.

Effective internal audit can reduce a company's external audit costs, but cannot eliminate its need for the company. It is also important to note that it is not recommended to use the services of the company's external auditor for internal audits, as such a combination may lead to loss of independence, which is one of the primary factors in the work of the external auditor.

The availability of effective internal audit today is an integral part of the successful development of the entity in the face of constant changes in the external environment and the complexity of management processes. It is used to monitor compliance with legislation, internal norms and rules, control the optimal use of resources, identify and prevent risks, ensure the reliability of information in reporting, etc.

Despite some difficulties, the introduction of a mandatory organization of the internal audit service of financial companies in Ukraine has significant advantages, which are provided by increasing the overall efficiency of organizations.

Key words: internal audit, internal audit service, financial companies, investments.

Фінансові компанії є представниками великого бізнесу, важливими платниками податків, їх виплати забезпечують стабільність економіки в цілому. Значній частині фінансових компаній характерна складність організаційної структури і віддаленість їх філій від 
дирекцій і деякі з них працюють на міжнародних ринках і потребують залучення іноземних партнерів. А отже, існує необхідність створення служби внутрішнього аудиту, 3 метою отримання надійної, повної і достовірної інформації про стан справ фінансових компаній, перевірки відповідності дотримання законодавства, політики, планів, підвищення довіри контрагентів до вітчизняного бізнесу, що зумовлює актуальність дослідження.

Внутрішній аудит як функція управління дає змогу вчасно виявити й усунути ті умови та чинники, які не сприяють ефективному веденню діяльності і досягненню поставленої мети, скоригувати діяльність компанії й окремих його складових, встановити, які саме служби і підрозділи компанії, а також напрями його діяльності сприяють досягненню поставлених цілей і підвищенню результативності діяльності компанії. Внутрішній аудит у сучасних умовах відіграє важливу роль у досягненні як стратегічних, так і оперативних цілей, спрямованих на підвищення конкурентоспроможності та ефективне управління компанії. Внутрішній аудит сприяє компанії в досягненні поставлених цілей за допомогою використання послідовного та систематизованого підходу до оцінки та підвищення ефективності процесів контролю, управління ризиками, а також корпоративного управління.

Теоретико-методичні та організаційні засади внутрішнього аудиту фінансових компаній знайшли відображення у роботах таких вчених-економістів: А.О. Касич [6], Л.А. Лещій [7], Ж.В.Прокопенко [9] та ін. Проте важливість організації служби внутрішнього аудиту фінансових компаній на сучасному етапі розвитку економіки потребує додаткового дослідження.

За визначенням Міжнародних стандартів аудиту внутрішній аудит - це діяльність 3 оцінювання, яка організована в межах суб'єкта господарювання і яку виконує окремий відділ. Функції внутрішнього аудиту охоплюють, зокрема, перевірку, оцінювання та моніторинг адекватності й ефективності функціонування систем бухгалтерського обліку і внутрішнього контролю. Функції внутрішнього аудиту можуть виконувати спеціальні служби або окремі аудитори, які перебувають у штаті компанії. Отже, внутрішній аудит - це незалежна діяльність на підприємстві, метою якої $є$ отримання достовірної та повної інформації для прийняття обгрунтованих управлінських рішень, сприяння ефективному виконанню завдань та досягнень цілей підприємства. Внутрішній аудит є невід'ємною частиною системи внутрішнього контролю і виконує в системі управління такі завдання:

- нагляд за дотриманням законодавства, внутрішніх норм і правил;

- збереження та захист активів підприємства та власників;

- контроль за оптимальним використанням ресурсів суб'єкта господарювання;

- визначення та попередження ризиків бізнесу;

- забезпечення достовірності й повноти інформації та звітності;

- проведення стратегічного аналізу та розробка фінансових прогнозів;

- забезпечення та сприяння виконанню планів та досягненню мети діяльності підприємства.

Головною метою внутрішнього аудиту $\epsilon$ пошук шляхів підвищення ефективності діяльності підприємства. Об'єкти внутрішнього аудиту з'ясовуються залежно від виду діяльності суб'єкта господарювання.

Розглядаючи питання про форму організації внутрішнього аудиту на конкретному підприємстві, слід підкреслити, що це питання також має вирішуватися власником або керівником залежно від мети і завдань, поставлених перед цією службою. У будь-якому разі служба внутрішнього аудиту має бути укомплектована кваліфікованими кадрами, які зможуть виконувати покладені на них функціональні обов'язки. Набагато важливіше місце внутрішнього аудиту в організаційній структурі підприємства, оскільки від цього значною мірою залежить ступінь об'єктивності результатів іiі діяльності. Основна ознака, за якою внутрішній аудит відрізняють від зовнішнього, полягає в тому, що він залежний, тобто підпорядкований керівництву тієї компанії, де він проводиться. Проте об'єктивність внутрішнього аудиту забезпечується ступенем його незалежності в організаційній структурі управління компанії. Функції внутрішнього аудиту мають визначатися керівництвом або власником підприємства залежно від змісту і специфіки діяльності підприємства. Однак можна виділити низку типових функцій, притаманних внутрішньому аудиту, незалежно від особливостей діяльності підприємства, на якому він проводиться.

Система внутрішнього аудиту повинна бути організована на такому рівні, щоб іiі результати контролю об'єктивно відображали діяльність підрозділів, які перевіряються, а також були доступними для розуміння всім користувачам такої інформації. У своїй діяльності фінансова компанія може вибрати будьяку форму організації внутрішнього аудиту. 


\section{ВНУТРІШНІЙ АУДИТ В СИСТЕМІ ФУНКЦІОНУВАННЯ} ФІНАНСОВИХ КОМПАНІЙ

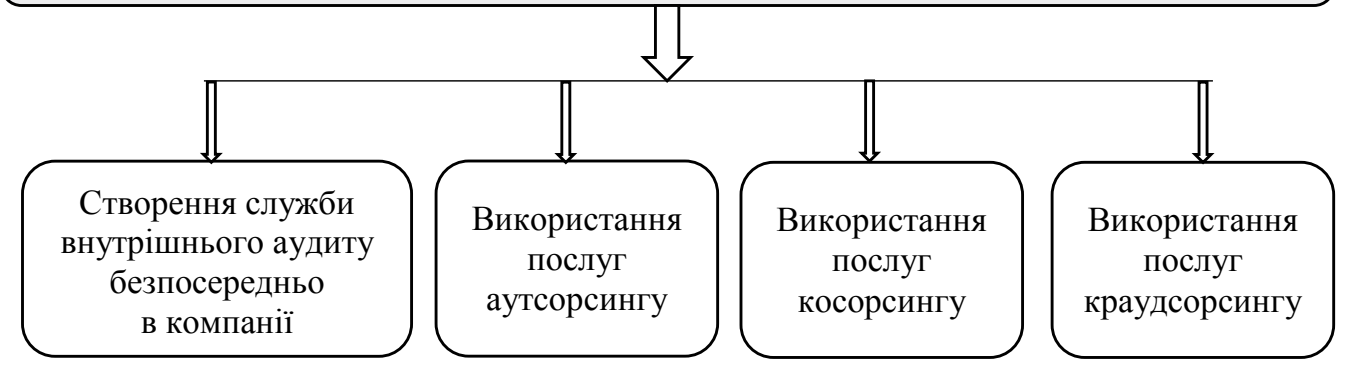

Рис. 1. Внутрішній аудит в системі функціонування фінансових компаній

Служба внутрішнього аудиту на підприємстві має розв'язувати завдання економічної діагностики, контрольного характеру, розроблення фінансової стратегії, управлінського консультування тощо.

Використання аутсорсингових послуг передбачає повну передачу функцій внутрішнього аудиту спеціалізованій компанії або зовнішньому консультанту. Однак недоліком такого аудиту є те, що суб'єкти внутрішнього аудиту менш обізнані зі специфікою бізнесу та діяльності фінансової компанії. Такі послуги будуть ефективними для малого бізнесу, який не може проводити постійний внутрішній аудит [6].

Альтернативою $є$ використання косорсингу (партнерства між замовником та зовнішнім постачальником), який пропонує переваги аутсорсингу при збереженні ефективних частин функцій внутрішнього аудиту фінансової компанії [7].

Косорсинг як організація служби внутрішнього аудиту передбачає розподіл функцій між відповідальними службами компанії та зовнішньою спеціалізованою компанією, яка бере участь у створенні служби внутрішнього контролю для вирішення певних проблем у процесі своєї роботи . Таким чином, косорсинг дає змогу якісно вирішити поставлені завдання за раціональних затрат. Косорсинг найбільш доцільно використовувати середнім підприємствам, які прагнуть розвивати свій бізнес 3 найбільш ефективним використанням наявних ресурсів [9].

Краудсорсинг (англ. crowd - натовп) - маловідома, але перспективна форма внутрішнього аудиту. Суть краудсорсингу полягає в тому, щоб надати в мережі Інтернет певне завдання колу осіб, які зацікавилися його виконанням. Після виконання завдання в установлені терміни краудсорсери пропонують свої варіанти його виконання замовнику, який розглядає їх і вибирає найбільш оптимальні, впроваджуючи у свою діяльність.
На основі зазначених напрямів реалізації можна виділити найсуттєвіші переваги організації служби внутрішнього аудиту фінансової компанії:

по-перше, отримання загальної експертної оцінки бізнесу;

по-друге, виявлення «слабких сторін» фінансових компаній, на основі аналізу поточного стану, з метою підвищення ефективності функціонування;

nо-третє, прогноз і оцінка перспектив діяльності компаній, забезпечення стабільного розвитку в умовах конкуренції;

по-четверте, забезпечення системи внутрішнього контролю з вимогами законодавства, контроль $з$ управління ризиками, підвищення надійності інформації;

no-n'яте, скорочення витрат на зовнішню перевірку, при якій враховуються результати внутрішнього аудиту;

по-шосте, сприяння поглибленню міжнародної співпраці 3 країнами Свропейського союзу, які вимагають «прозорості» ведення бізнесу без корупційних явищ і неможливості ухилення від сплати податків.

Належно організована робота внутрішнього аудиту, а особливо в умовах виходу з економічної кризи, спонукатиме працівників компанії дотримуватися чинного законодавства та нормативних актів, а також розробленої підприємством політики, планів, внутрішніх правил та процедур, вчасно виявляти та знижувати ризик непередбачених витрат чи втрати репутації фінансової компанії. Форми організації служби внутрішнього аудиту на окремому підприємстві повинні вирішуватися власником або керівником залежно від цілей та задач, поставлених перед цією службою, але в будь-якому випадку служба внутрішнього аудиту повинна бути укомплектована професійно придатними, кваліфікованими кадрами, які здатні виконати покладені на них функціональні обов'язки. 
Ефективний внутрішній аудит може знизити витрати компанії на зовнішній аудит, але не може скасувати його необхідність для компанії. Також важливо врахувати те, що не рекомендується користуватися послугами зовнішнього аудитора компанії для проведення внутрішніх аудитів, оскільки подібне поєднання може призвести до втрати принципу незалежності, що $є$ одним із першорядних чинників у роботі зовнішнього аудитора [8].

Позитивними рисами дії аудиту на підприємстві є те, що:

- внутрішній аудит допомагає забезпечити ефективність діяльності апарату управління щодо захисту законних майнових інтересів підприємства;

- удосконалює систему бухгалтерського обліку і сприяє підвищенню ефективності роботи;

- контролює реалізацію, надходження грошових коштів, придбання товарів і послуг тощо;

- зміцнює фінансовий стан підприємства;

- сприяє покращенню якості зовнішніх аудиторських перевірок;

- внутрішнім аудиторам потрібно докласти менше часу і зусиль для виявлення наявних відхилень;

- внутрішній аудит зазвичай краще забезпечує потребу підприємства у попередньому, поточному і наступному контролі.

Негативними рисами організації внутрішнього аудиту на підприємстві $\epsilon$ такі:

- недостатньою мірою виконується принцип незалежності аудитора;

- існує можливість побудови помилкового уявлення зовнішніх аудиторів про фінансовий стан підприємства на основі ознайомлення зі звітами внутрішніх аудиторів;

- одноразові аудиторські послуги зі сторони коштують дешевше, ніж постійний контроль 3 боку внутрішніх аудиторських служб.

Зазначимо, що наявність служби внутрішнього аудиту $є$ нормою для більшості великих міжнародних компаній, а отже впровадження внутрішнього аудиту сприяє підвищенню довіри іноземних інвесторів до українських компаній.

Разом $з$ тим, існують і певні труднощі, які гальмують розвиток внутрішнього аудиту, такі як:

- недостатня кількість кваліфікованих аудиторів;

- неефективні процедури щодо підготування документів і звітів про виконану роботу;

- витрати щодо розробки і впровадження системи внутрішнього аудиту;

- а щодо організації - то вагомішим було б, щоб служба внутрішнього аудиту підкорялась вищому рівню управління та ін.

Отже, наявність ефективного внутрішнього аудиту сьогодні є невід'ємною складовою успішного розвитку суб'єкта господарювання в умовах постійних змін зовнішнього середовища та ускладнення процесів управління. За його допомогою здійснюється нагляд за дотриманням законодавства, внутрішніх норм та правил, контроль за оптимальним використанням ресурсів, визначення та попередження ризиків, забезпечення вірогідності інформації у звітності тощо.

На сьогодні практика використання внутрішнього аудиту в Україні недостатньо розвинена, що насамперед пов'язано з відсутністю законодавчого регулювання цього процесу, єдиних вимог до професійного рівня внутрішніх аудиторів та професійних стандартів. 3 огляду на перспективність впровадження внутрішнього аудиту в практику управління вітчизняних суб'єктів господарювання, актуалізується необхідність його законодавчого забезпечення та теоретичного обгрунтування. Вибір найефективніших методів і технологій внутрішнього.

Незважаючи на певні труднощі, впровадження в Україні обов'язкової організації служби внутрішнього аудиту фінансових компаній має значні переваги, які забезпечуються підвищенням зальної ефективної діяльності організацій.

\section{Література:}

1. Про фінансові послуги та державне регулювання ринків фінансових послуг / Закон України від 12.07.2001 p. № 2664-III (редакція станом на 01.01.2017 р.).

2. Про затвердження порядку проведення внутрішнього аудиту (контролю) у фінансових установах / Нацкомфінпрослуг; Розпорядження, Порядок від 5 червня 2014 р. № 1772.

3. Міжнародні стандарти контролю якості, аудиту, огляду, іншого надання впевненості та супутніх послуг: Вид. 2015 р. Ч. 1,2: пер. 3 англ. Київ: Міжнар. Федерація бухгалтерів: Аудит. Палата України, 2016. 1249 c.

4. Бардаш С.В. Економічний контроль в Україні : системний підхід : монографія. К. : Київ. нац. торг.екон. ун-т, 2010. $656 \mathrm{c}$.

5. Каменська Т.О. Внутрішній аудит: методологія та організація : дис. докт. екон. наук: 08.00.09. К., 2011. $560 \mathrm{c}$. 
6. Касич А.О., Гноєва І.М. Особливості розвитку аудиторських послуг в Україні та концептуальні підходи до їх класифікації. Вісник ЖДТУ. Сер.: Економічні науки. 2019. № 4 (54). С. 94-98.

7. Лещій Л.А. Переваги впровадження внутрішнього аудиту. Стратегія розвитку аудиту в умовах глобалізації економічних відносин : міжнар. наук.-практ. конф. (Київ, 31 березня - 1 квітня 2020 р.) : тези доп. с. 94).

8. Назарова К.О. Аудит: еволюція, потенціал, ефективність : монографія. К. : Київ. нац. торг.-екон. ун-т, 2015. $464 \mathrm{c}$.

9. Прокопенко Ж.В. Внутрішній аудит у системі управління ризиками лізингової компанії. Проблеми теорії та методології бухгалтерського обліку, контролю і аналізу. 2015. Вип. 2 (23). С. 219-237.

10. Петрик О.А. Стан та перспективи розвитку аудиту в Україні: методологічні та організаційні аспекти : дис. ... докт. екон. наук : 08.00.09 / Олена Анатоліївна Петрик. К., 2004. 436 с.

\section{References:}

1. On financial services and state regulation of financial services markets (2001) [Pro finansovi posluhy ta derzhavne rehuliuvannia rynkiv finansovykh posluh]. Law of Ukraine of 12.07.2001 No 2664-III (as of 01.01.2017) (In Ukrainian).

2. On approval of the procedure for conducting internal audit (control) in financial institutions (2014) [Pro zatverdzhennia poriadku provedennia vnutrishnoho audytu (kontroliu) u finansovykh ustanovakh]/ Natskomfinproslug; Order, Order of June 5, 2014. No 1772 (in Ukrainian).

3. International standards of quality control, audit, inspection, other assurance and related services (2016) [Mizhnarodni standarty kontroliu yakosti, audytu, ohliadu, inshoho nadannia vpevnenosti ta suputnikh posluh]. Part 1.2: lane. from English. Kyiv: International. Federation of Accountants: Audit. Chamber of Ukraine, 1249 p. (In Ukrainian).

4. Bardash C.V. (2010)Economic control in Ukraine: a systematic approach [Ekonomichnyi kontrol v Ukraini : systemnyi pidkhid], monograph. Kyiv: Kyiv. nat. University of Trade and Economics, 656 p. (in Ukrainian).

5. Kamenskaya T.O. (2011) Internal audit: methodology and organization [Vnutrishnii audyt: metodolohiia ta orhanizatsiia]: dis. Doctor of Economics: 08.00.09. K. 560 p. (In Ukrainian).

6. Kasic A.O., Gnoeva I.M. (2019) Peculiarities of audit services development in Ukraine and conceptual approaches to their classification [Osoblyvosti rozvytku audytorskykh posluh $\mathrm{v}$ Ukraini ta kontseptualni pidkhody do yikh klasyfikatsii]. Bulletin of ZhSTU. Economic Sciences. No 4 (54). pp. 94-98. (in Ukrainian).

7. Bream L.A. (2020) Advantages of internal audit implementation [Perevahy vprovadzhennia vnutrishnoho audytu]. Strategy of audit development in the conditions of globalization of economic relations : int. scientificpractical conf. (Kyiv, March 31 - April 1, 2020): thesis add. with. 94) (in Ukrainian).

8. Nazarova K.O. (2015) Audit: evolution, potential, efficiency: monograph [Audyt: evoliutsiia, potentsial, efektyvnist]. Kyiv: Kyiv. nat. trade and economy University, 464 p. (in Ukrainian).

9. Prokopenko Zh.V. (2015) Internal audit in the risk management system of a leasing company [Vnutrishnii audyt u systemi upravlinnia ryzykamy lizynhovoi kompanii]. Problems of theory and methodology of accounting, control and analysis. Issue. 2 (23). pp. 219-237. (in Ukrainian).

10. Petrik O.A. (2004) Status and prospects of audit development in Ukraine: methodological and organizational aspects [Stan ta perspektyvy rozvytku audytu v Ukraini: metodolohichni ta orhanizatsiini aspekty]: dis. ... Dr. econ. Sciences: 08.00.09. K. 436 p. (in Ukrainian). 